\title{
Evaluation of Water Quality Index Using Physicochemical Characteristics of Ogbor River in Aba, Abia State, Nigeria
}

\author{
${ }^{1}$ OKEY-WOKEH, CG; ${ }^{1}$ OBUNWO, CC; ${ }^{2}$ WOKEH, OK
}

\author{
${ }^{I}$ Department of Chemistry, Rivers State University, Port Harcourt, PMB 5080, Nkpolu-Orowurukwo, Nigeria. \\ ${ }^{2}$ Department of Animal and Environmental Biology, University of Port Harcourt, PMB 5323, Port Harcourt, Nigeria \\ *Corresponding Author email: chidinmanti@yahoo.com, Tel: +2348032681947
}

\begin{abstract}
The study was carried out to evaluate water quality index (WQI) of Ogbor River, a freshwater system flowing through the commercial city of Aba, Southern Nigeria using selected physicochemical parameters. The levels of the physicochemical parameters were determined using standard analytical procedures in the Laboratory. The values obtained were subjected to statistical analysis using Excel spreadsheet (Version 16). Water Quality index was calculated using mean values of the selected nine parameters and the World Health Organisation standard for drinking water. The result of physicochemical parameters used showed that Dissolved Oxygen (DO) with mean $4.44 \pm 0.70 \mathrm{mg} / \mathrm{L}$, and Nitrate $\left(\mathrm{NO}_{3}^{-}\right)$with mean $7.58 \pm 6.25 \mathrm{mg} / \mathrm{L}$ were below National and International standards. The value of WQI calculated was 83.05 . The result revealed that Ogbor River water quality was very poor, so it is unfit for human consumption, and should be treated to avoid water related diseases.
\end{abstract}

DOI: $\underline{\text { https://dx.doi.org/10.4314/jasem.v25i1.6 }}$

Copyright: Copyright (C) 2021 Okey-Wokeh et al. This is an open access article distributed under the Creative Commons Attribution License (CCL), which permits unrestricted use, distribution, and reproduction in any medium, provided the original work is properly cited.

Dates: Received: 02 October 2020; Revised: 26 November 2020; Accepted: 12 December 2020

Keywords: Characteristics, Evaluation, Ogbor River, Physicochemical, Water Quality Index.

Water is an important resource for life support and undeniably, there is hardly any human activity without the use of water. The earth is occupied by water, of which $97 \%$ are saline in the oceans, while $3 \%$ is freshwater contained in the poles (i.e. in the form of ice), rivers, lakes, streams and groundwater which supply most of human and animal needs (Al-Ghamdi et al., 2014). Water can be sourced principally from surface waters which include streams, rivers, lakes and lagoons (Okey-Wokeh et al., 2020). Rivers are key sources of water supply for human in most societies, used for consumption, irrigation and industrial purposes (Seng et al., 2018). The usability of surface water is based on the water quality which is a prerequisite in determining the health of any society (Ezemonye et al., 2016). Unfortunately, many literatures have reported of high levels of deterioration of river water quality occasioned by arrays of anthropogenic activities (Edori and Kpee 2016). Therefore, the evaluation of water quality has been considered as an important aspect of water management strategy, but since it involves the measurement of large number of parameters, it has been considered as a complex task. Thus, water quality index (WQI) was employed to aggregate different parameters into single numerical value to determine the suitability of water quality for human consumption.
Water Quality Index (WQI) provides a single numerical value that expresses overall water quality at a certain location and time based on several water quality parameters available (Otene and Nnadi, 2019). It is a useful and efficient method for assessing the suitability of water quality by incorporating data obtained from multiple water quality parameters into a mathematical equation that rates the healthiness of water body with number (Akoteyon et al., 2011).Water Quality Index is one of the most effective ways to communicate information on water quality trend in water bodies to water quality managers and give the public general idea on possible problem with the water body (Boah et al., 2015). It is against this backdrop, that evaluation of the water quality of Ogbor River was carried out, owing to the fact that there has been paucity of research work in recent times on the Ogbor River water quality using water quality index (WQI).

\section{MATERIALS AND METHODS}

Description of Study Area: One river of significance in Nigeria is Ogbor River, a tributary of Imo River which originates from Ngwa hinterland of $\mathrm{Aba}$ and discharges into Opobo, where it then empties into the Atlantic Ocean with its creeks. The area lies within Latitude $5^{0} 05$ to $5^{0} 30^{1} \mathrm{~N}$ and Longitude $7^{0} 15$ to $7^{0} 40^{1} \mathrm{E}$ in the commercial city of Aba, Abia State (as shown in 
Figure 1), and is characterized by a low elevation and near flat topography. Ogbor River became an area of research interest because of arrays of anthropogenic activities prominent around the river course, which include Abattoir business, auto-mechanics, car wash, dredging and discharge of industrial effluents from nearby companies.

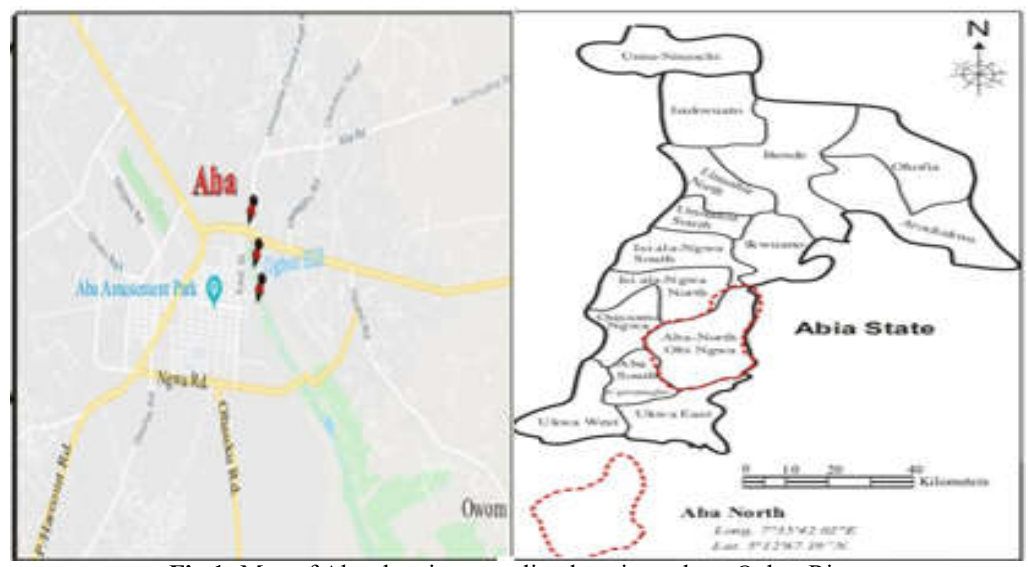

Fig 1: Map of Aba showing sampling locations along Ogbor River

Sample Collection and Analysis: Samples of water of Ogbor River were collected monthly for 12 months. The samples were collected at different points. Temperature was measured in situ by the use of mercury-in-glass thermometer, $\mathrm{pH}$ was measured and analyzed in situ with the aid of electric digital $\mathrm{pH}$ meter, while EC and TDS levels were measured in situ by the use of Hanna portable conductivity meter which was handheld. The levels of other physicochemical parameters were determined using standard procedures in the laboratory as described by APHA (1998).

Determination of Water Quality Index: The water quality index was calculated using the weighted arithmetic method by Boah et al (2015). The mean values of nine physicochemical parameters obtained from the sample station were used: $\mathrm{pH}, \mathrm{DO}, \mathrm{BOD}_{5}$, Total Hardness, Nitrate, Phosphate, Chloride, TDS and EC. The standard values set by WHO for drinking water was followed in the calculation using the general equation:

$$
W Q I=\frac{\sum \mathrm{QnWn}}{\sum \mathrm{Wn}}
$$

Where: Qn = Quality Rating; Wn = Unit Weight

The quality rating was determined using the formular:

$Q n=\frac{100(\mathrm{Vn}-\mathrm{Vio})}{(\mathrm{Sn}-\mathrm{Vio})}$

Where: Vn - Estimated value for nth water quality parameters of collected samples; Sn - Standard permissible value of the nth water quality parameters;
Vio - Ideal value of the nth water quality parameter in pure water (it is 0 for all other parameters except for $\mathrm{pH}$, which is 7 and DO which is 14.6).

The unit weight (Wn) was obtained by calculating a value inversely proportional to the recommended standard value $(\mathrm{Sn})$ of the corresponding parameter, ( ie $\mathrm{Wn}=1 / \mathrm{Sn})$.

Statistical Analysis: All the statistical analysis was performed using the Excel Spreadsheet (Version 16).

\section{RESULTS AND DISCUSSION}

Physicochemical parameters of Ogbor River: Table 1 presents the results of physicochemical parameters of fresh Surface water samples collected from Ogbor River.

Water $\mathrm{pH}$ : The test for river water $\mathrm{pH}$ was done to measure the acidic and alkaline condition of the river, since it affects river productivity and is considered to be of practical great importance, influencing most of the chemical and biochemical reactions (Taskeena et al., 2017). The result shown in Table 1 revealed that $\mathrm{pH}$ values ranged from $5.70-7.30$ with a mean value $(6.30 \pm 0.39)$. The river water was slightly acidic and fell below National and International permissible limits. This finding was similar to the reports of AmahJerry et al (2017) in Aba River. The low pH value observed in Ogbor River was an indication of river badly impacted by anthropogenic activities (Edokpayi et al., 2016), which could be attributed to discharge of organic refuse, municipal drains, sewage discharge and industrial effluents (Arimieari et al., 2014). 


\begin{tabular}{lllll}
\multicolumn{5}{c}{ Table 1: Mean of Physicochemical Parameters of Ogbor River } \\
\hline Parameters & Mean \pm SD & Range & WHO Limits & FMEnv Limits \\
\hline $\mathrm{pH}$ & $6.30 \pm 0.39$ & $5.70-7.30$ & $6.50-8.50$ & $6.50-8.50$ \\
$\mathrm{EC}(\mu \mathrm{S} / \mathrm{cm})$ & $756.98 \pm 454.51$ & $182.00-1572.00$ & 1000.00 & 500.00 \\
$\mathrm{TDS}(\mathrm{mg} / \mathrm{L})$ & $371.41 \pm 127.10$ & $200.00-677.30$ & 500.00 & 500.00 \\
$\mathrm{Cl}(\mathrm{mg} / \mathrm{L})$ & $5.84 \pm 3.64$ & $2.10-12.94$ & 250.00 & 100.00 \\
$\mathrm{TH}(\mathrm{mg} / \mathrm{L})$ & $30.55 \pm 10.73$ & $14.16-57.19$ & 500.00 & - \\
$\mathrm{DO}(\mathrm{mg} / \mathrm{L})$ & $4.44 \pm 0.70$ & $3.10-5.94$ & $5.00-7.00$ & 5.00 \\
$\mathrm{BOD}_{5}(\mathrm{mg} / \mathrm{L})$ & $3.27 \pm 1.76$ & $2.10-12.97$ & $2.00-5.00$ & 10.00 \\
$\mathrm{NO}_{3}{ }^{-}(\mathrm{mg} / \mathrm{L})$ & $7.58 \pm 6.25$ & $2.16-24.40$ & 50.00 & $10.00-20.00$ \\
$\mathrm{PO}_{4}{ }^{3-}(\mathrm{mg} / \mathrm{L})$ & $2.01 \pm 1.35$ & $0.47-5.12$ & 6.50 & 10.00 \\
\hline
\end{tabular}

Electrical Conductivity (EC): This is an important physicochemical parameter considered as an indirect indicator of pollution, due to the close relationship it bears with the dissolved salt content present in water column, that is often associated to sewage discharge (Taskeena et al., 2017).

The result shown in Table 1, revealed that the values of EC ranged from $182-1572.00 \mu \mathrm{S} / \mathrm{cm}$ with a mean value $(756.98 \pm 454.51 \mu \mathrm{s} / \mathrm{cm})$, which was within World Health Organisation (WHO) standards, but above Federal Ministry of Environment (FMEnv) standards for fresh water. The high values of EC could also be as a result of industrial waste, agricultural runoff and domestic discharges, which makes this water body unfit for human consumption (Otene and Nnadi, 2019).

Total Dissolved Solids (TDS): The presence of dissolved solids in water is a measure for salinity and its high content affects the density of water, which influences freshwater organisms and reduces solubility of gases such as oxygen (Ogundele and Mekuleyi, 2018). The values of TDS shown in Table 1 revealed that TDS ranged from $200-677.30 \mathrm{mg} / \mathrm{L}$, with a mean value of $371.41 \pm 127.098 \mathrm{mg} / \mathrm{L}$. High values of TDS causes harmful effects to public health such as damage of central nervous system, dizziness and provoking paralysis of tongue (Gupta et al., 2017). Although, the TDS values obtained in this study, fell within 500 $\mathrm{mg} / \mathrm{L}$ WHO standard and FMEnv permissible limits for drinking water.

Chloride $\left(\mathrm{Cl}^{-}\right)$: Chloride is present in all types of water body in varying concentrations but excessive chloride in surface water impacts a salty taste (Ogbonna et al., 2019). The values of chloride as shown in Table 1 revealed that the values ranged from $2.10-12.94$ $\mathrm{mg} / \mathrm{L}$, with a mean value of $5.84 \pm 3.64 \mathrm{mg} / \mathrm{L}$. This value obtained was far below the permissible limits of $250 \mathrm{mg} / \mathrm{L}$ and $100 \mathrm{mg} / \mathrm{L}$ recommended by $\mathrm{WHO}$ and FMEnv respectively, which is an indication that Ogbor River is a fresh water ecosystem.

Total Hardness (TH): This is one of the physicochemical characteristics of surface water, used to describe the effect of dissolved minerals, particularly calcium and magnesium in determining suitability of water for domestic and industrial purposes (Adewoye et al., 2013). The total hardness values recorded in this study ranged from 14.16 $57.19 \mathrm{mg} / \mathrm{L}$, with a mean value of $30.55 \pm 10.73$. The values of $\mathrm{TH}$ observed in this study were below 500 $\mathrm{mg} / \mathrm{L}$ guideline set by National and International organizations. Therefore, this river water is categorized as soft water.

Dissolved Oxygen (DO): The test for dissolved oxygen was carried out to measure the changes that occurred in biological parameters due to aerobic or anaerobic phenomenon, and to know the condition of the river water which is vital for aquatic organisms as well as human life (Gupta et al., 2017). The result in Table 1 revealed that DO values ranged from $3.10-5.94 \mathrm{mg} / \mathrm{L}$ with a mean value of $4.44 \pm 0.70 \mathrm{mg} / \mathrm{L}$. The $\mathrm{DO}$ value is slightly below the National (FMEnv) and International (WHO) standards for fresh water. The low DO observed in this study could be attributed to abattoir and sewage discharges into the water body, and this is in conformity with the reports of AmahJerry et al. (2017) in Aba River. Low DO level is an indication of pollution in water and can lead to impaired fish development and maturation (OkeyWokeh et al., 2020).

Biochemical Oxygen Demand $\left(B O D_{5}\right)$ : This is the oxygen required for micro-organisms to perform biological decomposition of dissolved solids in water (Qureshimatva et al., 2015). The $\mathrm{BOD}_{5}$ values obtained in this study ranged from $2.10-12.97 \mathrm{mg} / \mathrm{L}$, with a mean value of $3.27 \pm 1.76$. The BOD value recorded in this study is within both National and International permissible limits. Although, BOD values within $2.0-2.9 \mathrm{mg} / \mathrm{L}$ is indicative of pollution, while those above $3.0 \mathrm{mg} / \mathrm{L}$ are regarded as highly polluted and unfit for human consumption (Afolabi et al., 2012). Therefore the BOD value recorded in this study is an indication of pollution, which could be attributed to high level of organic content of abattoir effluent released into the water body.

Nitrate $\left(\mathrm{NO}_{3}^{-}{ }^{-}\right)$: The presence of nitrate in surface water indicates the presence of fully oxidized matter which 
originates from anthropogenic activities such as municipal sewage, runoff water from agricultural lands and discharges from households (Adewoye et al., 2013). From the result in Table 1, the concentration of $\mathrm{NO}_{3}{ }^{-}$ranged from $2.16-24.40 \mathrm{mg} / \mathrm{L}$ with a mean value of $7.58 \pm 6.25 \mathrm{mg} / \mathrm{L}$. The values obtained in this study were below National and International standards for fresh surface water.

Phosphate $\left(\mathrm{PO}_{4}{ }^{3-}\right)$ : Phosphate is a limiting nutrient for algal growth and controls the primary productivity of a water body, and as such, stands as indicator of anthropogenic and biological pollution (Kidu et al., 2015). The values of phosphate in this study ranged from $0.47-5.12 \mathrm{mg} / \mathrm{L}$, with a mean value of $2.01 \pm$ $1.35 \mathrm{mg} / \mathrm{L}$. The concentrations of $\mathrm{PO}_{4}{ }^{3-}$ obtained in this study fell below the National (FMEnv) and International (WHO) permissible limits for fresh surface water. The low phosphate value observed in this study is in agreement with the report of Egbuonu et al. (2018) in Waterside River, Ogbor Hill, Aba. Low phosphate concentration is a common feature of tropical fresh water bodies (Tony et al., 2018).

Classification of water quality: A classification of water quality based on the weighted arithmetic water quality index (WQI) method is presented in Table 2. In the classification, a WQI ranging between 0 and 25 is rated excellent water quality and graded as $\mathrm{A}$, whereas an index greater than 100 is considered unsuitable for drinking purpose and is graded as E.

Water Quality Evaluation: The result of water quality index (WQI) evaluation in Ogbor River is presented in Table 3 .

Table 2: Classification of Water Quality based on Weighted Arithmetic WQI Method

\begin{tabular}{lll}
\hline WQI & Rating of Water Quality & Grading \\
\hline $0-25$ & Excellent water quality & $\mathrm{A}$ \\
$26-50$ & Good water quality & $\mathrm{B}$ \\
$51-75$ & Poor water quality & $\mathrm{C}$ \\
$76-100$ & Very poor water quality & $\mathrm{D}$ \\
$>100$ & Unsuitable for drinking purpose & $\mathrm{E}$ \\
\hline
\end{tabular}

(Source: Boah et al., 2015)

\begin{tabular}{|c|c|c|c|c|c|c|c|}
\hline $\begin{array}{l}\mathbf{S} / \\
\mathbf{N}\end{array}$ & Parameter & $\begin{array}{l}\text { Experiment } \\
\text { al Value }\end{array}$ & $\begin{array}{l}\text { Standard } \\
\text { Value (Sn) }\end{array}$ & $1 / \mathbf{S n}$ & $\begin{array}{l}\text { Unit Weight } \\
\text { (Wn) }\end{array}$ & $\begin{array}{l}\text { Quality } \\
\text { Rating (Qn) }\end{array}$ & QnWn \\
\hline 1 & $\mathrm{pH}$ & 6.23 & 6.50 & 0.154 & 0.209 & 140.0 & 29.26 \\
\hline 2 & $\mathrm{EC}(\mu \mathrm{s} / \mathrm{cm})$ & 756.98 & 1000.00 & 0.001 & 0.0014 & 75.698 & 0.106 \\
\hline 3 & TDS (mg/L) & 371.41 & 500.00 & 0.002 & 0.0027 & 74.282 & 0.201 \\
\hline 4 & $\mathrm{Cl}^{-}(\mathrm{mg} / \mathrm{L})$ & 5.84 & 250.00 & 0.004 & 0.0054 & 2.336 & 0.103 \\
\hline 5 & $\mathrm{TH}(\mathrm{mg} / \mathrm{L})$ & 30.55 & 500.00 & 0.002 & 0.0027 & 6.110 & 0.016 \\
\hline 6 & $\mathrm{DO}(\mathrm{mg} / \mathrm{L})$ & 4.44 & 5.00 & 0.200 & 0.271 & 105.83 & 28.681 \\
\hline 7 & $\mathrm{BOD}_{5}(\mathrm{mg} / \mathrm{L})$ & 3.27 & 5.00 & 0.200 & 0.271 & 65.400 & 17.723 \\
\hline 8 & $\mathrm{NO}_{3}^{-}(\mathrm{mg} / \mathrm{L})$ & 7.58 & 50.00 & 0.020 & 0.0271 & 15.160 & 0.411 \\
\hline 9 & $\mathrm{PO}_{4}{ }^{3-}(\mathrm{mg} / \mathrm{L})$ & 2.01 & 6.50 & 0.154 & 0.209 & 30.923 & 6.463 \\
\hline$\sum$ & & & & 0.737 & 0.999 & & 82.964 \\
\hline
\end{tabular}

$W Q I=\sum Q n W n / \sum W n \quad=82.964 / 0.999=83.047$

Therefore, WQI for Ogbor River $=83.047 \approx \mathbf{8 3 . 0 5}$

Water Quality Index: From the result obtained in the calculation of water quality index as shown in Tables 2 and 3, it was observed that the value of WQI in Ogbor River fell within the range of $76-100$ (see Table 2), which is a very poor water quality and unsuitable for human consumption. Ogbor River should therefore be properly treated if it must be used for domestic purpose (drinking), to avoid water related diseases.

Conclusion: The study evaluated water quality index using physicochemical characteristics, and the results of physicochemical parameters showed that the river water was badly impacted by anthropogenic activities.
The result of water quality index calculated revealed that water quality of Ogbor River is very poor and must be treated before use to avoid water related diseases.

\section{REFERENCES}

Adewoye, SO; Adewoye, AO; Opasola, OA; Elegbede, JA (2013) Physicochemical Parameters and Heavy Metal Analysis of Water Samples from Hand Dug Wells in Gambari, Ogbomosho, Oyo State. J.Environ. Sci. Toxicol. Food Tech. 5(1): 2230 .

Afolabi, TA; Ogbuneke, CC; Ogunkunle, OA; Bamiro, FO (2012). Comparative Assessment of the Portable Quality of Water from Industrial, Urban and Rural Parts of Lagos, Nigeria. Ife J. Sci. 14(2): $46-51$ 
Akoteyon, IS; Omotayo, AO; Soladoye, O; Olaoye, HO (2011). Determination of Water Quality Index and Suitability of Urban River for Municipal Water Supply in Lagos Nigeria. Europ. J.Sci. Res. 5(2): $263-271$

Al-Ghamdi, AY; Mohamed, EIS; Al-Ghamdi, AO; Zabin, SA (2014). Study of Physicochemical Properties of the Surface and Ground Water. Am. J.Environ. Sci. 10 (3): $219-235$

Amah-Jerry, EB; Anyanwu, ED; Avoaja, DA (2017). Anthropogenic Impacts on the Water Quality of Aba River South East Nigeria. Ethiop.J.Environ. Stud.Manag. 10(3): 299-314

American Public Health Association (APHA) (1998). Standard Methods for the Examination of Water and Waste Water. 20 $0^{\text {th }}$ Edition. Washington D.C., U. S. A

Arimieari, LW; Sangodoyin, AY; Ereoforiokuma, NS (2014). Assessment of Surface Water Quality in some Selected Locations in Port Harcourt, Nigeria. Int.J.Eng. Res.Technol. (IJERT). 3(7): 1146-1151

Boah, DK; Twum, SB; Pelig-Ba, KB (2015). Mathematical Computation of Water Quality Index of Vea Dam in Upper East Region of Ghana. Environ. Sci. 3(1): $11-16$

Edokpayi, JN; Odiyo, JO; Popoola, OE; Msagati, TAM (2016). Assessment of trace metals contamination of surface water and sediments: A case study of Mundi River, South Africa. MDPI Sustainab. 8(135): 1-13

Edori, OS; Kpee, F (2016). Physicochemical and Heavy Metal Assessment of Water Samples from Boreholes Near some Abattoirs in Port Harcourt, Rivers State, Nigeria. Am. Chem. Sci. J. 14(3): 1-8

Egbuonu, ACC; Atasie, OC; Oyedemi, SO (2018). Quality Assessment of Waterside River, Ogbor Hill Aba 3: Effects of Three-Point Samples of Kidney Histo-architecture and Some Seric Biofunctional Indicator of Wistar Rats. Res. J. Environ. Sci. 12 (1): $14-20$

Ezemonye, MN; Osiatuma, SI; Emeribe, CN (2016). Impact of Abattoir Waste on the Physicochemical Quality of Anwai River, Asaba, Delta State, Nigeria. Europe. Sci. J. 12(20): 277 - 288

Gupta, N; Pandey, P; Hussain, J (2017). Effect of Physicochemical and Biological Parameters on the Quality of River Water of Narmada, Madhya Pradesh, India. J. Wat. Sci. 31(1)
Kidu, M; Gebrekidan, A; Hadera, A; Weldegebriel, Y (2015). Assessment of Physicochemical Parameters of Tsaeda Agam River in Mekelle City, Tigray Ethiopia. Bull. Chem. Soc. Ethiop. 29 (3): $377-385$

Ogbonna, DN; Ogbuku, JO; Kporman, LB (2019). Influence of Open Drainage Channels in Port Harcourt. As. J.Adv.Res. Rep. 3(1): 1 - 10

Ogundele, O; Mekuleyi, GO (2018). Physicochemical properties and heavy metal concentration in waste water discharged from two industries in Agbara, Lagos State Nigeria. Int. Res. J. Pub. Environ. Health. 5(3) 32-37.

Okey-Wokeh, CG; Obunwo, CC; Boisa, N (2020). Assessment of Physicochemical Characteristics of Mini-Ezi Stream in Elele-Alimini, Emohua Local Government Area of Rivers State, Nigeria. Int.J.Adv. Sci. Res. Eng.(IJASRE), 6 (1): $1-8$.

Otene, BB; Alfred-Ockiya, JF (2019). Human and Ecological Risk Assessment of Heavy Metals in Water and Sediment of Elechi Creek, Port Harcourt, Nigeria. J.Environ. Sci.Toxicol. Food Tech. 13(3): $01-07$.

Otene, BB; Nnadi, PC (2019). Water Quality Index and Status of Minichindah Stream, Port Harcourt, Nigeria. Int.J.Geo.Environ.Manage. 5(1): 1 - 9.

Qureshimatva, UM; Maverya, RR; Gamit, SB; Patel, RD; Solanki, HA (2015). Determination of Physicochemical Parameters and Water Qality Index (WQI) of Chanlodia Lake, Ahmedabad Gujarat, India. J. Environ. Anal. Toxicol. 5 (4): 288.

Seng, CY; Rath, T; Lim, S; Eav, C; Phan, K (2018). Assessment of Physicochemical Properties of the River Water in Phnom Penh and its Suburban Area. Bull. Cambo. Chem. Soc. 9(1-2): 29-35.

Taskeena, H; Saltanat, P; Bilal, NB; Uzma, A (2017). Seasonal Variations in Water Quality Parameters of River Yamuna, India. Int. J. Curr. Appl. Sci. 6(5):694.

Tony, RFN; Ogbuagu, DH; Ebe, TE; Ezike, MN; Egbuawa, IO (2018). Investigation of Physiochemical Parameters and Plankton Biotopes in Ntawogba Creek, Diobu, Port Harcourt. J. Wat. Res. Ocea. Sci. 7(3): 20-27. 